\title{
Breakdown and microbial uptake of marine viruses and other lysis products
}

\author{
Rachel T. Noble*, Jed A. Fuhrman \\ University of Southern California, AHF 107, University Park, Los Angeles, California 90089-0371, USA
}

\begin{abstract}
To understand the roles of marine viruses in marine microbial food webs, it is important to determine rates and mechanisms of virus degradation and subsequent uptake of degraded virus material and other cell lysis products by heterotrophic marine bacteria. We radiolabeled and concentrated viruses and viral lysis products from either pure cultures $\left({ }^{3} \mathrm{H}\right)$ or natural communities $\left({ }^{3} \mathrm{H}\right.$ and $\left.{ }^{33} \mathrm{P}\right)$ and added them to seawater samples of differing trophic status from coastal (mesotrophic) and offshore (oligotrophic) California waters and French Mediterranean waters (oligotrophic). Rates of degradation were determined by the loss of high molecular weight radiolabel over time and the fate of the degraded material (microbial uptake or accumulation in low molecular weight pools) was followed by size fractionation and/or acid extraction. Preliminary experiments with ${ }^{3} \mathrm{H}$-labeled, single-stranded RNA phage MS2 and marine phage H11/1 demonstrated that MS2 degraded significantly faster in coastal Santa Monica Bay seawater $\left(2.5 \pm 0.6 \% \mathrm{~h}^{-1}\right)$, than the marine phage, H11/1 $\left(0.99 \pm 0.1 \% \mathrm{~h}^{-1}\right)$. For labeled virus material from natural populations, rates of degradation were slower in oligotrophic waters (ranges from 1.0 to $3.3 \% \mathrm{~h}^{-1}$ ) than in mesotrophic waters (ranges from 4.9 to $6.0 \% \mathrm{~h}^{-1}$ ), corresponding to turnover rates of 1 to $4 \mathrm{~d}$ for this material. Degradation rates of labeled virus material are likely underestimates, because during preparation, degradation and uptake are continually occurring, resulting in accumulation of the less reactive products. The proportion of radiolabeled material taken up by microbes was greatest in oligotrophic waters, especially in the phosphate-limited Villefranche Bay, France, where most of the ${ }^{33} \mathrm{PO}_{4}$-labeled material was taken up in less than $7 \mathrm{~h}$. In contrast, the majority of degraded ${ }^{3} \mathrm{H}$-labeled material was not accumulated into biomass, and in 3 of 4 samples, accumulation was hardly detectable. The results suggest that viruses and lysis products are labile and turn over relatively rapidly, but often may not be efficiently incorporated into bacterial biomass.
\end{abstract}

KEY WORDS: Virus · High molecular weight - Viral lysis products

\section{INTRODUCTION}

Understanding the processes that control degradation of virus particles has been methodologically limited by our ability to trace virus particles over time. Even though the presence of marine viruses has been known for quite some time (ZoBell 1946. Spencer 1955), it is only within the last decade that the quantitative importance of marine viruses has been repeatedly demonstrated, (e.g. Proctor et al. 1988, Bergh et al. 1989, Cochlan et al. 1993, Hennes \& Suttle 1995). It has recently been shown that viruses are significant agents of mortality of prokaryotes in the oceans, and in

•E-mail: noble@usc.edu certain marine environments, viruses and protists can contribute equally to bacterial mortality (Fuhrman \& Noble 1995, Steward et al. 1996). By direct counts, viral abundances have been observed to change rapidly during phytoplankton blooms (Bratbak et al. 1990), slowly over longer-term seasonal scales in ocean waters (Jiang \& Paul 1994), and spatially from nearshore to offshore ocean waters (Cochlan et al. 1993, Paul et al. 1993) and from surface waters to deep waters (Cochlan et al. 1993, Weinbauer et al. 1995, Noble \& Fuhrman $1998 \mathrm{~b}$ ). The ratio of viral to bacterial numbers in surface waters is typically 5-15:1 (Børsheim 1993, Cochlan et al. 1993, Noble \& Fuhrman $1998 \mathrm{~b})$. It is thought that viral and bacterial processes are very tightly coupled and that rates of virus production increase with increasing bacterial density (Murray 
\& Jackson 1992, Steward et al. 1992). Knowing that viruses are ubiquitous to the world's oceans (Fuhrman \& Suttle 1993), that they have important roles in the marine microbial food web, and that the products of viral infection may be useful to bacteria for growth (Middelboe et al. 1996), the next logical question involves the fates of viruses and viral lysis products in the marine environment.

In the last 3 decades, the fates of viruses in the marine environment have largely been studied by loss of infectivity. Some attempts have been made to quantify the rates and understand the mechanisms of viral decay in whole seawater samples (Heldal \& Bratbak 1991), but most studies have been performed with cultured marine phage/host systems isolated directly from seawater (e.g. Zachary 1976, Moebus \& Nattkemper 1983, Suttle \& Chen 1992, Noble \& Fuhrman 1997). Thcse studies are limited by the culturability of marine bacteria, which may represent as little as $0.1 \%$ of the total bacterial diversity (Ferguson et al. 1984, Staley \& Konopka 1985, Lee \& Fuhrman 1991). The results of these attempts have shown that loss of viral infectivity occurs at a range of rates from ca 1 to $20 \% \mathrm{~h}^{-1}$, that rates of decay are different for different viruses, and that sunlight and biochemical conditions play important roles in the decay (Suttle \& Chen 1992, Suttle et al. 1992, Noble \& Fuhrman 1997). Loss of infectivity is not necessarily coupled to the process of degradation, because viral infectivity may be affected by different factors than viral particle disappearance (Wommack et al. 1996). Even though sunlight is a major factor influencing rates of loss of infectivity (Suttle \& Chen 1992), components of seawater (dissolved organic matter [DOM], particulate matter, exoenzymes, proteases, nucleases and other bioactive molecules) are also important contributors to the decay of viral infectivity and are probably important agents of viral degradation (Noble \& Fuhrman 1997).

The fates of viruses from the perspectives of molecular degradation and the cycling of viral matter have not been carefully examined. In order to trace the paths of viruses and viral lysis products in the marine environment, we have taken 2 approaches. Preliminary experiments examined the fates of cultured viruses by adding radiolabeled viruses back into seawater and tracing the radiolabeled material over time. In later experiments, radiolabeled virus concentrates made from natural mixed virus assemblages were added back into seawater and the fates of these 'natural' radiolabeled viruses and high molecular weight (HMW) viral lysis products were followed over time. Natural communities of viruses and viral lysis products were used because cultured marine bacteriophage may not always be representative of the populations found in the marine environment (Børsheim 1993). In the exper- iments using natural populations of radiolabeled viruses, the virus material was traced by using 2 different radiolabels, ${ }^{3} \mathrm{H}$ and ${ }^{33} \mathrm{P}$, which specifically label certain types of molecules. Tritiated amino acids are incorporated into proteins, DNA and/or major metabolic intermediates, and the label may also be respired. Tritiated thymidine will be incorporated primarily into DNA, and when bacterial cells utilize it for other cellular constituents, and the radiolabel may also be respired. ${ }^{33} \mathrm{PO}_{4}$ is incorporated primarily into nucleic acids and phospholipids.

By tracing viruses and viral lysis products through degradation and possible uptake, we may be able to determine the importance of virus-mediated processes in different marine environments. There has been speculation that the importance of virus infection to heterotrophic bacterioplankton is directly related to the trophic status of the seawater (Weinbauer et al. 1993, 1995, Wilcox \& Fuhrman 1994, Fuhrman \& Noble 1995, Steward et al. 1996). Weinbauer et al. (1993) saw an increase in the frequency of infected bacteria and virus production rates with increasing trophic status, and suggested that with increasing bacterial abundances, viruses contribute more to bacterial mortality. A higher incidence of bacterial cell lysis means that more viruses are produced, and because the viral and bacterial populations are often in steady state, it is likely that rates of viral loss would also be higher. Additionally, it has been suggested in the past that the DOM release subsequent to viral infection (viruses are operationally considered DOM due to their size) that occurs in marine planktonic systems may have direct impacts on the system as a whole (Fuhrman 1992). If most of this material becomes a substrate for growth of heterotrophic bacteria, then this release becomes an important recycling step within the marine microbial food web, especially in oligotrophic nutrient-limited waters where bacterioplankton can take advantage of the nitrogen and phosphorus-rich products of cell lysis for growth (Middelboe et al. 1996). Because bacteria are rich in $\mathrm{N}$ and $\mathrm{P}$ (compared to other pico- and nanoplankton cells), this process may also enhance retention and regeneration of $\mathrm{N}$ and $\mathrm{P}$, especially in the upper water column, and increase bacterial uptake of certain growth substrates.

\section{MATERIALS AND METHODS}

Laboratory culture experiments. The marine host bacteria were isolated as single colonies from concentrated seawater spread onto Moebus seawater (MSW) agar plates $(0.1 \%$ yeast extract, and $0.5 \%$ peptone in $80 \%$ glass fiber filtered seawater) as by Moebus (1980). Host bacteria, Escherichia coli 3000 (for phage 
MS2) and H11 (for phage H11/1), were grown from a single colony overnight in $25 \mathrm{ml}$ of LB broth and MSW liquid media, respectively. In the morning, the $25 \mathrm{ml}$ of host bacterial culture were added to either $225 \mathrm{ml}$ of LB broth or MSW liquid media along with $20 \mu \mathrm{Ci}$ each ${ }^{3} \mathrm{H}$ alanine, glycine, leucine, serine, and thymidine $\left(1 \mu \mathrm{Ci} \mu 1^{-1}\right)$. The bacterial culture was grown to mid-log phase (determined by previous growth curve experiments), and high-titer virus stock was added at the closest approximation to a multiplicity of infection of 1 . The cultures of bacteria were allowed to 'clear' to ensure release of all viruses from infected cells, and the remaining viral lysate and cellular debris was centrifuged in $30 \mathrm{ml}$ conical tubes in a fixed-angle Sorvall SS-34 rotor in a Sorvall centrifuge RC5B at $3500 \times g$, $10^{\circ} \mathrm{C}$. Bacterial cells that remained intact plus particulate debris were removed from the viral lysate by filtering the supernatant fluid through a $0.2 \mu \mathrm{m}$ Acrodisc (Whatman). The HMW material in the $0.2 \mu \mathrm{m}$ filtrate was concentrated with Centriprep 30 concentration units (Amicon, Inc) to a final volume of about $10 \mathrm{ml}$. This material was further concentrated in a smaller volume concentration unit, Centricon 30 (Amicon, Inc.), to a final volume of ca $2 \mathrm{ml}$. The concentrated viral lysate was washed by resuspension and reconcentration at least 3 times with $2 \mathrm{ml}$ aliquots of sterilized, $0.02 \mu \mathrm{m}$ filtered seawater (Anopore, Whatman) to remove any remaining growth media. After each reconcentration step a small aliquot of sample was saved for virus counts (to examine the structural integrity of the viruses by transmission electron microscopy [TEM]) and total radioactivity counts. The final 'hot' lab cultured viral lysates were sonicated with a Branson ultrasonic bath $(80 \mathrm{~W}$ ) for $20 \mathrm{~s}$ (to disperse clumped viruses) and added to freshly collected Santa Monica Bay seawater.

Seawater samples were collected in an acid-rinsed bucket from Santa Monica Pier, California, USA $\left(34^{\circ}\right.$ $05^{\prime} \mathrm{N}, 118^{\circ} 30^{\prime} \mathrm{W}$ ), transported to the University of Southern California (USC) within $30 \mathrm{~min}$, and processed within $1 \mathrm{~h}$. The radiolabeled material was added to duplicate bottles for the following 4 treatments of seawater: untreated, $1.0 \mu \mathrm{m}$ filtered, formalin-killed (control), and $1.0 \mu \mathrm{m}$ filtered and formalinkilled (control). The bottles were incubated in a laboratory incubator on a 12:12 h light:dark cycle at $18.2^{\circ} \mathrm{C}$. The bottles were subsampled over time with the following series of duplicate filtrations and acid extractions: (1) samples of $0.5 \mathrm{ml}$ were taken for determination of total radioactivity, (2) size fractionation used a 10-place Hoefer filtration manifold with the following filtrations (a) microbial uptake was determined by the radiolabeled material retained by a $0.2 \mu \mathrm{m}$ Nuclepore filter, (b) HMW material was quantified as the trichloroacetic acid (TCA) insoluble material retained by a $0.45 \mu \mathrm{m}$ filter, and (c) low molecular weight (LMW) material was quantified by the material which was TCA soluble (passed through a $0.45 \mu \mathrm{m} \mathrm{HA}$ Millipore after TCA extraction). For each TCA extraction, $4 \mathrm{ml}$ of sample was pipetted into an ice-cold stainless steel tower and $2 \mathrm{ml}$ cold 10\% TCA was added. After 2 min, the entire sample was filtered through a $0.45 \mu \mathrm{m}$ pore size HA Millipore filter. After collecting the filtrates in scintillation vials, the towers were rinsed 3 times with $5 \%$ TCA. The towers were removed and the edges of the filters were also rinsed 3 times with $5 \%$ TCA. Filters were put directly into scintillation vials with $5 \mathrm{ml}$ scintillation fluid and counted.

Natural virus populations. The general approach was to radiolabel natural populations of viruses by incubating seawater with various radioisotopes, concentrate the radiolabeled viruses and viral lysis products and to add the concentrate back into seawater at tracer levels.

Sample collection. Seawater samples for the experiments using natural populations of marine viruses were taken from a range of marine environments in 4 locations, listed from most productive to least productive; in the Southern California Bight at Paradise Cove, California $\left(34^{\circ} 01^{\prime} \mathrm{N}, 118^{\circ} 47^{\prime} \mathrm{W}\right)$, Two Harbors, Catalina Island $\left(33^{\circ} 27^{\prime} \mathrm{N}, 118^{\circ} 30^{\prime} \mathrm{W}\right)$, Villefranche Bay in the French Mediterranean, Villefranche-surMer, France $\left(43^{\circ} 41^{\prime} \mathrm{N}, 07^{\circ} 18^{\prime} \mathrm{E}\right)$ and offshore California waters $\left(190 \mathrm{~km}\right.$ offshore, $\left.32^{\circ} 51^{\prime} \mathrm{N}, 120^{\circ} 42^{\prime} \mathrm{W}\right)$. Experiments at Two Harbors and Paradise Cove were done on 9 June 1995 and 11 June 1995, respectively. The experiment in Villefranche Bay was on 11 July 1996 and that with offshore California waters was on 25 May 1997.

Preparation of virus concentrate. Seawater incubation volumes were $20 \mathrm{l}$ for Paradise Cove and Two Harbors, and 21 for Villefranche Bay and offshore California waters. In brief, the seawater was filtered through a Gelman glass fiber filter (to remove protists and zooplankton) and incubated over a period of 24 to $36 \mathrm{~h}$ in the dark with a total of $100 \mu \mathrm{Ci}$ each of ${ }^{3} \mathrm{H}$ thymidine and leucine, a high specific activity mixture of ${ }^{3} \mathrm{H}$ amino acids (Amersham, Inc.), and ${ }^{33} \mathrm{PO}_{4}$, and pulsed with $20 \mu \mathrm{Ci}^{-1}$ of each radiolabel every $8 \mathrm{~h}$. In the experiment with offshore California waters, $4 \mu \mathrm{Ci} \mathrm{l}^{-1}$ of ${ }^{35} \mathrm{~S}$ methionine was also added every $8 \mathrm{~h}$ for ca $36 \mathrm{~h}$. Following incubation, the seawater was filtered with a $142 \mathrm{~mm} 0.22 \mu \mathrm{m}$ pore size Durapore to remove bacteria and protists, and for the $20 \mathrm{l}$ incubations, the virussized fraction (material between $0.2 \mu \mathrm{m}$ and $30 \mathrm{kD}$ ) was concentrated using a spiral cartridge concentration system (Amicon, Inc.) to a final volume of a few hundred $\mathrm{ml}$. This material was further concentrated to ca $10 \mathrm{ml}$ using Centriprep 30 concentration units ( $30 \mathrm{kD}$ molecular weight cutoff). The 21 incubations were concentrated using the Centriprep 30 concentra- 
tion units as well. This concentrate contained 'hot' viruses and lysis products and for the remainder of this paper will be referred to as the HMW concentrate (HMWC) or 'virus concentrate'. A small portion of the HMWC was fixed with $2 \%$ (final concentration) $0.02 \mu \mathrm{m}$ filtered formalin and stored at $4^{\circ} \mathrm{C}$; within $1 \mathrm{wk}, 100 \mu \mathrm{l}$ drops of the HMWC were spotted onto formvar-coated copper grids for observation by TEM and $200 \mu \mathrm{l}$ subsamples of concentrate were diluted with $3.8 \mathrm{ml} 0.02 \mu \mathrm{m}$ Anopore-filtered deionized water and counted by TEM by the method outlined below. At Villefranchesur-Mer, after the concentration step, virus counts were performed immediately on the concentrate using the stain SYBR Green I following the method of Noble \& Fuhrman (1998b).

Recovery of viruses by the concentration methods outlined above ranged from 45 to $66 \%$ as calculated by the increase in the virus concentration versus the volume concentration factor. By knowing the volume concentration factor, and with an estimated recovery of $50 \%$, virus concentrate was added back into the duplicate seawater samples at tracer levels of virus abundance $(<10 \%$ of original abundance). Samples were incubated at ambient seawater temperatures in 50\% sunlight. The same filtration and size fractionation steps were performed in duplicate as with the cultured virus experiments (see 'Laboratory culture experiments'). However, HMW and LMW material was quantified in 2 ways: acid extraction and size fractionation. HMW material was measured as material retained by an Anopore (Whatman) $0.02 \mu \mathrm{m}$ filter or TCA insoluble material retained by a $0.45 \mu \mathrm{m}$ filter; LMW material was that material that passed through an Anopore $0.02 \mu \mathrm{m}$ filter or that was TCA soluble (passed through a $0.45 \mu \mathrm{m}$ HA Millipore after TCA extraction).

Rates of degradation of the HMW radiolabeled virus material in all of the experiments were determined by linear regression of a semi-log plot of total $\mathrm{dpm}$ in the TCA insoluble or the $>0.02 \mu \mathrm{m}$ size fraction versus time. Labeling with ${ }^{35} \mathrm{~S}$ methionine was not measurable, and with ${ }^{33} \mathrm{PO}_{4}$ was not measurable in 3 of the 4 experiments (signal indistinguishable from background). On a semi-log plot of log dpm versus time, the slope of the line is the decay constant $\left(\mathrm{h}^{-1}\right)$ and the reciprocal is the projected turnover time of the virus population (assuming the radiolabeled viruses are representative of the natural virus population). Rates of degradation observed in formalin and heat-killed controls were subtracted from rates of degradation in untreated seawater. Additions of radiolabeled viruses to seawater were intended as tracer additions and in all cases the virus concentration was increased by less than $10 \%$ of the original virus concentration.
Virus and bacterial counts. Tranmission electron microscopy: Samples for virus and bacterial counts were fixed with $2 \%$ formalin (final concentration) and stored at $4^{\circ} \mathrm{C}$ in the dark. Viruses and bacteria were counted by TEM after ultracentrifugation of $4 \mathrm{ml}$ seawater samples onto copper grids (Børsheim et al. 1990, Cochlan et al. 1993). Grids were stained with $1 \%$ uranyl acetate for $30 \mathrm{~s}$. Viruses were counted at $27000 \times$ and bacteria at $10000 \times(80 \mathrm{keV})$ on a JEOL 100 CXII TEM.

Epifluorescence microscopy: In Villefranche-sur-Mer, epifluorescence microscopy was used to enumerate viruses and bacteria in seawater samples with the nucleic acid stain SYBR Green I (Molecular Probes, Inc.) following the method of Noble \& Fuhrman (1998b).

Bacterial growth rates. The thymidine incorporation method was modified from Fuhrman \& Azam (1982). At each time point, duplicate $42 \mathrm{ml}$ samples and $1 \%$ formalin-killed controls were subsampled into wellrinsed sterile $50 \mathrm{ml}$ polypropylene tubes (VWR brand). Samples were inoculated with $5 \mathrm{nM}\left({ }^{3} \mathrm{H}-\right.$ methyl) thymidine (Dupont New England Nuclear). Subsamples were incubated on board the ship or in the lab at seawater temperature under ambient light. After $30 \mathrm{~min}$ incubations, duplicate $20 \mathrm{ml}$ samples from each tube were filtered through HAWP Millipore filters (mixed cellulose acetate and cellulose nitrate, $0.45 \mu \mathrm{m}$ nominal pore size) in cold stainless steel filtration funnels in a 10-place manifold (Hoefer Scientific), then filtration valves were closed and $2 \mathrm{ml}$ ice-cold 5\% TCA was added. After $2 \mathrm{~min}$, the TCA was filtered through and the filters and funnels were rinsed 3 times with $1 \mathrm{ml}$ of cold $5 \%$ TCA, then the funnels were removed and the edge of the filters was rinsed 3 times with $1 \mathrm{ml} 5 \%$ TCA. Filters were placed in a glass $20 \mathrm{ml}$ vial and $1 \mathrm{ml}$ $1 \mathrm{~N} \mathrm{HCl}$ was added, followed by heating to $90-100^{\circ} \mathrm{C}$ in an oven for $1 \mathrm{~h}$ (to hydrolyze the nucleic acids). After the vials cooled, $5 \mathrm{ml}$ Ecoscint (National Diagnostics) was added and the samples were counted by liquid scintillation with dpm correction (Packard). Conversion factors used to calculate production from the moles of thymidine incorporated were the averages reported in Fuhrman \& Azam (1982) at $2 \times 10^{18}$ cells produced per mole thymidine incorporated. Bacterial counts were by SYBR Green I, and average bacterial counts were used to calculate turnover times for the bacterial population. These are reported in Table 1 (see 'Results').

Chlorophyll measurements. Samples for chlorophyll a (chl a) measurements were filtered at volumes from 250 to $500 \mathrm{ml}$ onto uncombusted Whatman GF/F or HA Millipore $0.45 \mu \mathrm{m}$ cellulose nitrate filters, extracted for $24 \mathrm{~h}$ in $90 \%$ acetone $\left(-20^{\circ} \mathrm{C}\right)$ and analyzed for chl $\mathrm{a}$ and phaeopigments by in vitro fluorometry by the method of Parsons et al. (1984). 


\section{RESULTS}

The concentrated, radiolabeled virus material was examined by either TEM (in California) or epifluorescence microscopy (in Villefranche-sur-Mer) for each experiment. By TEM, the concentrates appeared to be full of recognizable, free, intact virus particles that exhibited a variety of morphologies (many were tailed, icosahedral phage). Viruses were the most numerous type of particle in the concentrate, and were not noticeably clumped. The majority of the particles were lightly and uniformly stained. By SYBR Green I staining, viruses were uniformly stained and easy to count. Recovery of virus particles in the concentrates ranged from 45 to $66 \%$.

In preliminary experiments with the cultured phagehost systems, only TCA extraction was used to separate the HMW material from the LMW material. In later experiments with natural virus populations, direct size fractionation with a $0.02 \mu \mathrm{m}$ filter was found to be equivalent for the separation of intact viruses and other HMW viral lysis products from LMW degraded virus material. In the experiments that incorporated both TCA extraction and size fractionation, rates of degradation were not significantly different from each other ( $t$-test, $\mathrm{p}<0.05)$. From this point on, we will refer to material found in either the TCA insoluble pool or the $>0.02 \mu \mathrm{m}$ size fraction as HMW, and to the material in the TCA soluble pool or $<0.02 \mu \mathrm{m}$ size fraction as LMW, although distinctions may be made at certain times.

In general, at time zero, the sum of the radiolabeled material from each of the filtration steps accounted for the large majority of the total radioactivity in each experiment, and partitioning among 4 pools (HMW, LMW, material > $0.2 \mu \mathrm{m}$ [microbial uptake], and material lost due to adsorption) was followed over time. In the experiments with laboratory cultured bacteriophage, the radiolabeled HMW virus material initially represented 70 and $98 \%$ of the total radioactivity for H11/1 and MS2, respectively (data not shown), with the rest of the radiolabeled material being LMW. In 3 of the 4 experiments using ${ }^{3} \mathrm{H}$-labeled viruses from natural populations, $75 \%$ of the total added radioactivity was HMW material at time zero, while in the experiment with offshore California waters, only $40 \%$ of the ${ }^{3} \mathrm{H}$-label was found in the HMW fraction at the start of the experiment. Similarly, only about $32 \%$ of the ${ }^{33} \mathrm{P}$-labeled material was found in the HMW fraction at time zero in the Villefranche Bay experiment.

\section{Laboratory cultured bacteriophage experiments}

Bacteriophage MS2 is a small, single-stranded RNA, male specific Escherichia coli bacteriophage, while
$\mathrm{H} 11 / 1$ is a marine bacteriophage isolated from the North Sea. In experiments with both phages, the total radioactivity remained constant over the entire time course, i.e. there was little or no loss of the radioactive material due to adsorption. The sum of the radiolabel found in the HMW, LMW and microbial uptake pools was $85.3 \pm 8.0 \%$ of the measured total radioactivity over the entire time course.

MS2 degraded at a rate of $2.5 \pm 0.6 \% \mathrm{~h}^{-1}$ in untreated seawater over a period of $48 \mathrm{~h}$ (Fig. 1A). Within the first $20 \mathrm{~h}$, more than $50 \%$ of the radiolabeled HMW material was degraded into either LMW material or taken up by microbial assemblages (Fig. 1A). In the formalin-treated control, there was no detectable degradation of HMW material, accumulation of LMW material or microbial uptake (Fig. 1B). The rate of degradation of marine bacteriophage $\mathrm{H} 11 / 1$ was $0.99 \pm$ $0.1 \% \mathrm{~h}^{-1}$ in unfiltered, untreated seawater (Fig. $2 \mathrm{~A}$ ). By $20 \mathrm{~h}$, one-third of the H11/1 either degraded into LMW material or was taken up by microbial assemblages. A $1 \mu \mathrm{m}$ filtration of the seawater did not sig-

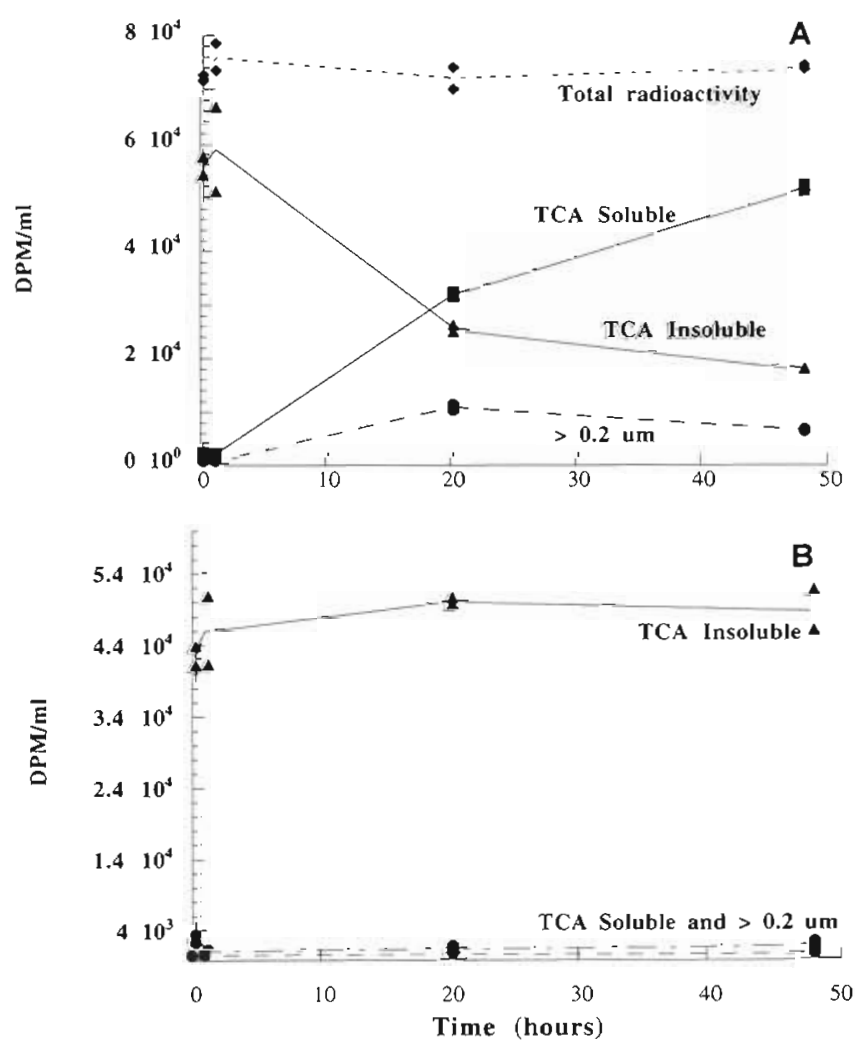

Fig. 1. (A) Fates of ${ }^{3} \mathrm{H}$-radiolabeled coliphage MS2 in untreated seawater. Total radioactivity $(\bullet)$, high molecular weight (HMW) material (TCA insoluble) ( $\mathbf{4}$ ), low molecular weight (LMW) material (TCA soluble) ( $\bullet$ ), and material $>0.2 \mu \mathrm{m}(\bullet)$. (B) Fates of ${ }^{3} \mathrm{H}$-radiolabeled coliphage MS2 in formalin-treated control seawater. HMW material (TCA insoluble) ( $₫$ ), LMW material (TCA soluble) and material $>0.2 \mu \mathrm{m}(\bullet)$ 

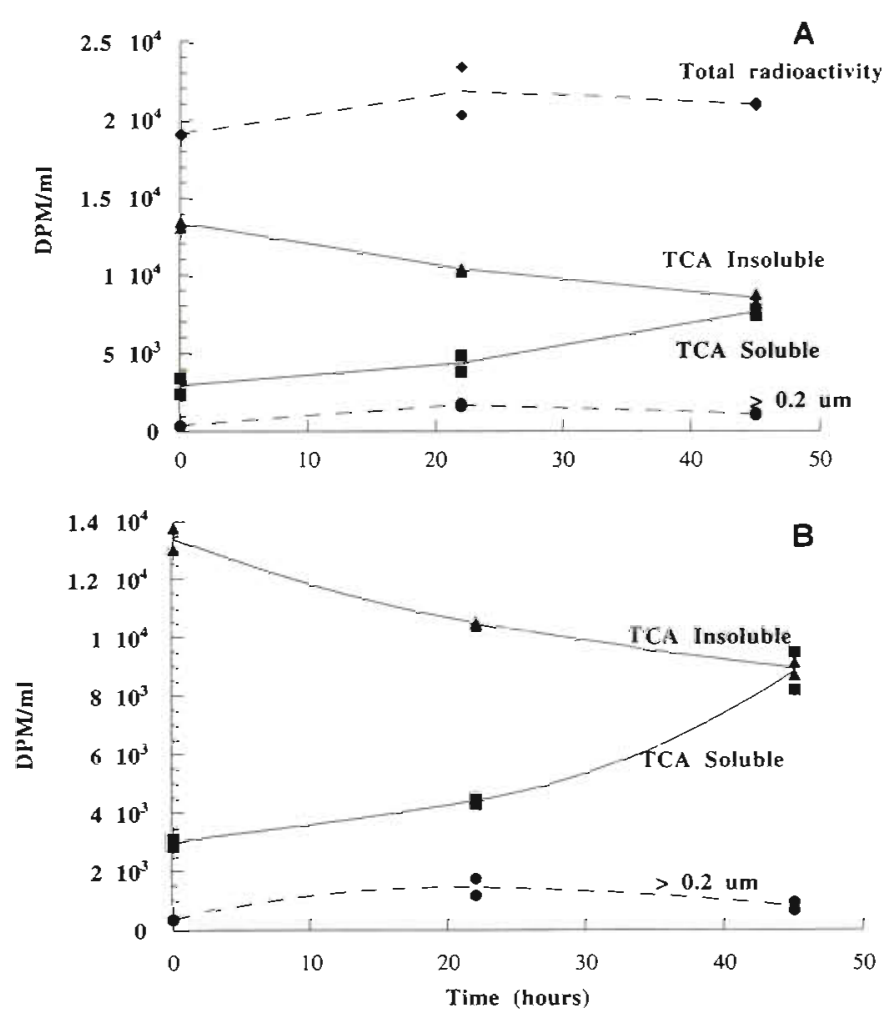

Fig. 2. (A) Fates of ${ }^{3} \mathrm{H}$-radiolabeled marine bacteriophage $\mathrm{H} 11 / 1$ in untreated seawater. Total radioactivity $(\bullet)$, HMW material (TCA insoluble) ( $\mathbf{\bullet}$ ), LMW material (TCA soluble) ( $\mathbf{-}$ ), and material $>0.2 \mu \mathrm{m}(\bullet)$. (B) Fates of ${ }^{3} \mathrm{H}$-radiolabeled marine bacteriophage $\mathrm{H} 11 / 1$ in $1.0 \mu \mathrm{m}$ filtered seawater. HMW mate-

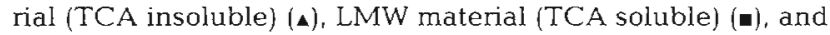
material $>0.2 \mu \mathrm{m}(\bullet)$ nificantly change the rate of degradation of $\mathrm{H} 11 / 1$ (Fig. 2B). Similar to the result with MS2, H11/1 incubated in formalin-treated seawater did not demonstrate any measurable changes in the different sizefractionated pools over time (data not shown).

\section{Natural populations of marine viruses}

A general characterization of all of the sites of the experiments, showing water temperature, cell and virus counts, chlorophyll concentrations, bacterial production measurements, and summarized rates of virus degradation, is shown in Table 1.

\section{Degradation of radiolabeled material}

At Paradise Cove, the rates of degradation of HMW virus material in untreated seawater were 4.9 and $6.0 \% \mathrm{~h}^{-1}$ as determined by acid extraction and size fractionation, respectively (Table 1 , Fig. 3A). In these incubations the turnover time of the viruses and viral lysis products was ca $18 \mathrm{~h}$. There was a negligible increase in the ${ }^{3} \mathrm{H}$ material found in the $>0.2 \mu \mathrm{m}$ size fraction (microbial uptake). Bacterial and viral abundances at the start of the experiment were $2.70 \times 10^{6}$ and $1.43 \times 10^{7} \mathrm{ml}^{-1}$, respectively. Viral abundances increased by ca $20 \%$, compared to the controls during the experiment, and bacterial abundances decreased slightly over the course of the experiment.

In the meso-oligotrophic waters of Two Harbors, rates of degradation of HMW virus material were

Table 1. Seawater characteristics and comparsion of virus degradation as determined by loss of ${ }^{3} \mathrm{H}$ radiolabeled HMW virus material in 4 experiments. nd: not determined

\begin{tabular}{|c|c|c|c|c|}
\hline \multicolumn{5}{|l|}{ Parameters } \\
\hline Location & $\begin{array}{l}\text { Paradise Cove, } \\
\text { Malibu, CA }\end{array}$ & $\begin{array}{c}\text { Two Harbors, } \\
\text { Santa Catalina Island }\end{array}$ & $\begin{array}{l}\text { Villefranche Bay } \\
\text { France (NW Med. Sea) }\end{array}$ & Offshore California Waters \\
\hline Date & 11 June 1995 & 9 June 1995 & 11 July 1996 & 26 May 1997 \\
\hline Water temperature $\left({ }^{\circ} \mathrm{C}\right)$ & 19.8 & 19.5 & 22.5 & 19.3 \\
\hline Mean bacterial abundance $\left(\mathrm{ml}^{-1}\right)$ & $2.74 \times 10^{6}$ & $1.04 \times 10^{6}$ & $5.34 \times 10^{5}$ & $1.15 \times 10^{6}$ \\
\hline Mean viral abundance $\left(\mathrm{ml}^{-1}\right)$ & $1.35 \times 10^{7}$ & $1.06 \times 10^{7}$ & $4.15 \times 10^{6}$ & $1.78 \times 10^{7}$ \\
\hline Bacterial turnover time (d) & 0.76 & 1.6 & 1.8 & 3.0 \\
\hline Chl a $\left(\mu \mathrm{g}^{-1}\right)$ & $5.0-10.6$ & $1.0-1.8$ & $0.2-0.6$ & $0.4-0.7$ \\
\hline Trophic status & Mesotrophic & Meso-oligotrophic & Oligotrophic & Oligotrophic \\
\hline $\begin{array}{l}\text { Rate of degradation } \\
\text { (by acid extraction, } \% \mathrm{~h}^{-1} \text { ) }\end{array}$ & $\begin{array}{l}4.9 \\
r^{2}=0.76\end{array}$ & $\begin{array}{c}2.9 \\
r^{2}=0.99\end{array}$ & $\begin{array}{c}3.3 \\
r^{2}=0.97\end{array}$ & nd \\
\hline $\begin{array}{l}\text { Rate of degradation } \\
\text { (by size fractionation } \% \mathrm{~h}^{-1} \text { ) }\end{array}$ & $\begin{array}{c}6.0 \\
\mathrm{r}^{2}=0.95\end{array}$ & $\begin{array}{c}3.4 \\
r^{2}=0.97\end{array}$ & $\begin{array}{c}3.0 \\
\mathrm{r}^{2}=0.70\end{array}$ & $\begin{array}{c}1.0 \\
r^{2}=0.91\end{array}$ \\
\hline
\end{tabular}


about $30 \%$ slower than those at Paradise Cove (Table 1, Fig. 3B) with an estimated turnover time of $1.3 \mathrm{~d}$. There was no increase in the ${ }^{3} \mathrm{H}$ material found in the $>0.2 \mu \mathrm{m}$ size fraction (Fig. 3B). Bacterial and viral abundances at time zero were lower than those observed in the Paradise Cove experiment, at $1.05 \times$ $10^{6}$ and $1.12 \times 10^{7} \mathrm{ml}^{-1}$, respectively. Viral abundances increased at $16 \mathrm{~h}$, and then declined back to control levels while bacterial abundances were essentially invariant.

In oligotrophic offshore California waters, rates of degradation of ${ }^{3} \mathrm{H}$-labeled HMW virus material were $1.0 \% \mathrm{~h}^{-1}$ as determined by size fractionation (Table 1 , Fig. $3 \mathrm{C}$ ), equating to a turnover time of the viral population of $4.2 \mathrm{~d}$. Uptake of ${ }^{3} \mathrm{H}$-labeled material in the $>0.2 \mu \mathrm{m}$ size fraction was negligible (Fig. 3C). Concentrations of bacteria and viruses were $1.03 \times 10^{6}$ and $1.13 \times 10^{7} \mathrm{ml}^{-1}$, respectively. Viral and bacterial counts changed very little compared to the controls over the course of the experiment.

In the Villefranche Bay experiment we were able to successfully analyze ${ }^{33} \mathrm{P}$ and ${ }^{3} \mathrm{H}$ labels separately in the same samples, as there was enough ${ }^{33} \mathrm{P}$-labeled material. In these oligotrophic waters, rates of degradation of ${ }^{3} \mathrm{H}$-labeled TCA insoluble and $>0.02 \mu \mathrm{m}$ material were 3.3 and $3.0 \% \mathrm{~h}^{-1}$, respectively (Table 1, Fig. 3D). The estimated turnover time of the ${ }^{3} \mathrm{H}$-labeled virus material was $1.4 \mathrm{~d}$. Microbial uptake of the ${ }^{3} \mathrm{H}$-labeled virus material was essentially linear, reaching about $20 \%$ of the total added radioactivity by $30 \mathrm{~h}$ (Fig. 3D). At the start of the experiment, there was more ${ }^{33}$ P-radiolabeled LMW virus material than HMW virus material. The rate of degradation of ${ }^{33} \mathrm{P}$-labeled $\mathrm{HMW}$ virus material ranged from 4.8 to $8.1 \% \mathrm{~h}^{-1}$, measured only in the first $7 \mathrm{~h}$. After the first $7 \mathrm{~h}$, there was no measurable degradation of HMW material. The LMW material was largely depleted within the first $7 \mathrm{~h}$ of the experiment, while within the same period, more than $50 \%$ of the ${ }^{33} \mathrm{P}$-radiolabel was taken up by the bacteria-sized

Fig. 3. (A) Fates of ${ }^{3} \mathrm{H}$-radiolabeled viruses in Paradise Cove seawater. Radiolabel is partitioned as follows: total radioactivity ( $\bullet$ ), HMW material (TCA insoluble) ( $)$ ), HMW material

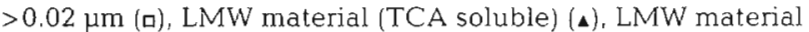
$<0.02 \mu \mathrm{m}(\boldsymbol{\bullet})$, and material $>0.2 \mu \mathrm{m}(\bullet)$. Error bars represent standard deviations calculated from duplicate measurements; where they are not shown they are less than the width of the symbols. (B) Fates of ${ }^{3} \mathrm{H}$-radiolabeled viruses in Two Harbors seawater. Symbols are the same as in (A). (C) Fates of ${ }^{3} \mathrm{H}$-radiolabeled viruses in Villefranche-sur-Mer seawater. Symbols are the same as in (A). (D) Fates of ${ }^{3} \mathrm{H}$-radiolabeled viruses in Villefranche-sur-Mer seawater. Symbols are the same as in (A). (E) Fates of ${ }^{3} \mathrm{H}$-radiolabeled viruses in offshore California seawater. Radiolabel is partitioned as follows: total radioactivity $(\bullet)$, HMW material $>0.02 \mu \mathrm{m}(\square)$, LMW material $<0.02 \mu \mathrm{m}$ $(\bullet)$, and material $>0.2 \mu \mathrm{m}(\bullet)$
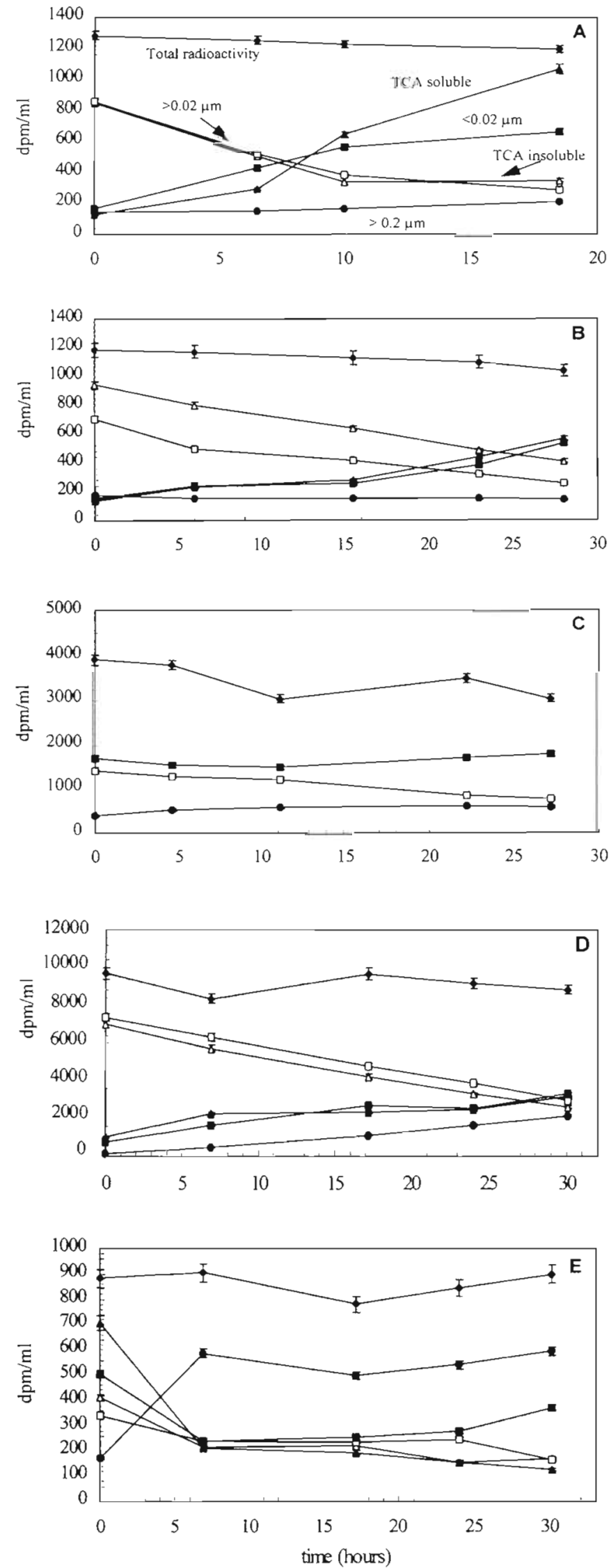
fraction (Fig. 3E). In the other 3 experiments, the incorporation of the ${ }^{33} \mathrm{P}$-radiolabel was not detectable above background once the concentrate was added into seawater. Bacterial and viral abundances at time zero were much lower in Villefranche Bay than for the other experiments, at $5.89 \times 10^{5}$ and $5.08 \times 10^{6} \mathrm{ml}^{-1}$, respectively. Virus counts in the untreated seawater remained constant over the course of the experiment, while virus numbers in the formalin-treated controls dropped slightly.

\section{Transformation of virus material}

The transformation of radiolabeled virus material was followed between 4 pools: (1) HMW, (2) LMW, (3) microbial uptake (material found in the $>0.2 \mu \mathrm{m}$ size fraction), or (4) adsorption (Fig. 4). As there was no significant difference between separation of HMW and LMW material by either acid extraction or size fractionation, only the results for size fractionation are presented. The relative amounts of radiolabel in each pool were calculated as a percent of the total radioactivity. In Paradise Cove seawater, half of the ${ }^{3} \mathrm{H}$-labeled HMW virus material degraded into LMW material within the first $6.5 \mathrm{~h}$, but there was little measurable microbial uptake or adsorption of the radiolabeled material during this time (Fig. 4). At Two Harbors, only about onesixth of the HMW material was degraded into LMW material within the first $6.5 \mathrm{~h}$ (Fig. 4). Similar to the experiment in Paradise Cove, there was no detectable microbial uptake or adsorption of radiolabeled material. In offshore California waters, the HMW material represented $40 \%$ of the total radiolabel at $0 \mathrm{~h}$. During the first $5 \mathrm{~h}$ of the experiment, only about one-tenth of the HMW material either degraded into LMW material or was taken up by microbes (Fig. 4). In oligotrophic seawater from Villefranche Bay, about one-third of the ${ }^{3} \mathrm{H}$-labeled HMW material was either broken down into LMW material or taken up by bacteria over the first $6.5 \mathrm{~h}$. Adsorption of radiolabel at $6.5 \mathrm{~h}$ was nearly $15 \%$ of the total radiolabel (Fig. 4). The distribution of radiolabel at the end of the experiments revealed that in incubations of Paradise Cove, Two Harbors, and offshore California seawater, only 20 to $25 \%$ of the total radiolabel remained as HMW material, about $60 \%$ had degraded into LMW material, 5 to $10 \%$ of the material was taken up by bacteria and larger organisms and 5 to $10 \%$ had adsorbed onto container walls (Fig. 4). BY the end of the incubations in Villefranche Bay, about $30 \%$ of the ${ }^{3} \mathrm{H}$-labeled material remained as HMW material, about $40 \%$ was LMW material, material taken up by microbes was $20 \%$ of the total, and that lost due to adsorption was about $10 \%$. In the Villefranche Bay experiment with ${ }^{33} \mathrm{PO}_{4}$, more than $50 \%$ of the available ${ }^{33} \mathrm{P}$-labeled material was taken up by microbial assemblages within $7 \mathrm{~h}$. However, at the start of the experiment, about half of the radiolabeled material was found in the LMW fraction. Between the $7 \mathrm{~h}$ time point and the end of the experiment, material did not shift appreciably between pools.

\section{DISCUSSION}

The aim of the experiments was to demonstrate the feasibility of using radiolabeled virus concentrates to trace the breakdown and microbial uptake of viruses and viral lysis products. Rates of loss of infectivity of MS2 and H11/1 were determined in parallel experiments. Comparisons between rates of degradation and loss of infectivity for H11/1 showed that loss of infectivity occurred faster than degradation (Noble \& Fuhrman 1997). With MS2, the rate of loss of infectivity in untreated seawater was 4 times faster at $10.2 \pm 1.1 \% \mathrm{~h}^{-1}$ (unpubl. data), and with $\mathrm{H} 11 / 1$ the rate of loss of infectivity was more than 5 times faster at $6.6 \pm 1.0 \% \mathrm{~h}^{-1}$ (Noble \& Fuhrman 1997). There are several reasons

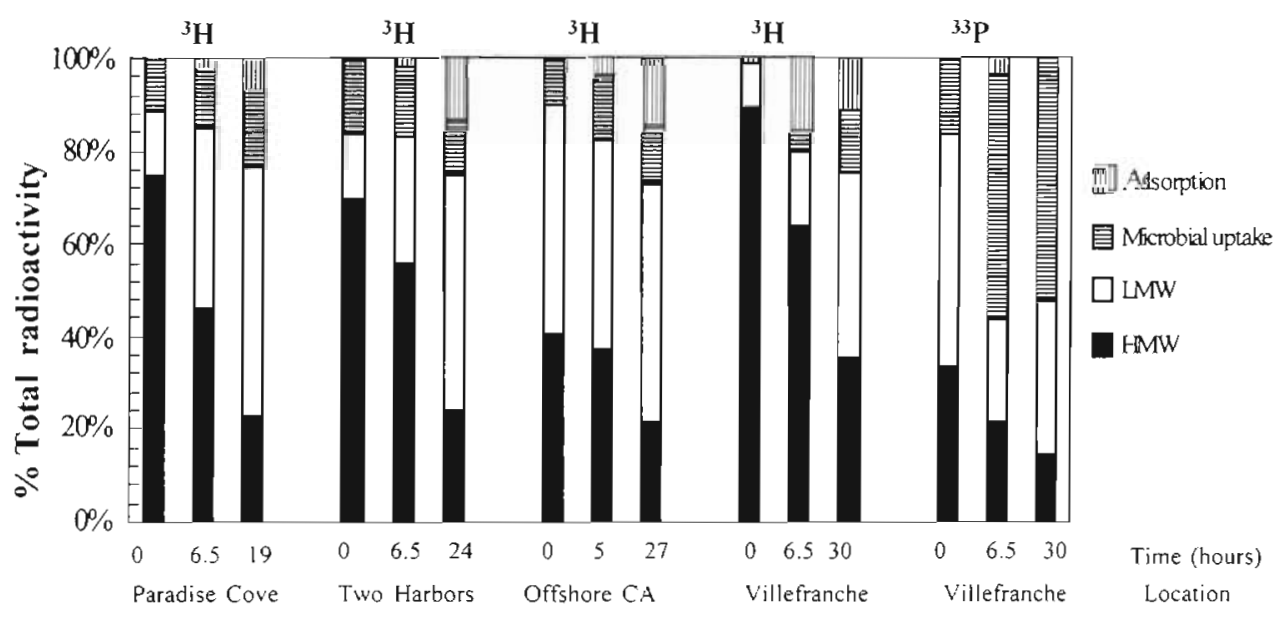

Fig. 4. Bar graph representation of the transformation of radiolabeled virus material between 4 pools as determined by size fractionation 
why virus degradation may occur at different rates and by different mechanisms than loss of viral infectivity. For example, loss of viral infectivity can occur with a single alteration in a tail fiber, breakage of the virus tail, capsid damage, a single mutation, etc., making it impossible for the virus to attach to its host and successfully reproduce. Also, viral lysates include cell debris resulting from cell lysis, which is likely to be more labile than intact viruses. Viruses that are adsorbed nonspecifically to particles often lose their infectivity because their attachment site has been blocked, but these adsorbed virus particles may actually be relatively protected from further degradation (Mitchell \& Jannasch 1969, Kapuscinski \& Mitchell 1980). It has been suggested in the past that biochemical degradation of virus particles in natural systems occurs at similar rates for many different viral taxa, but that the loss of infectivity of specific taxa can be different because of the susceptibility of certain types of viruses to sunlight, chemical inactivating agents, and enzymes. (Suttle \& Chen 1992, Suttle et al. 1992, Wommack et al. 1996, Noble \& Fuhrman 1997). However, our knowledge of rates of loss of infectivity versus degradation of specific viral taxa are limited by our ability to culture marine bacteria.

The rates of degradation of the single cultured radiolabeled phage were about half as fast as the rates of degradation of natural populations of radiolabeled viruses and viral lysis products. The rates of degradation in seawater inoculated with the radiolabeled natural populations of viruses are likely to be faster because the radiolabeled components include both viruses and viral lysis products. Similarly, the turnover times may be an underestimate of the virus population, because viral lysis products are probably more labile than intact virus particles. Also, because a longer time is required for the labeling and concentration steps, the intact viruses are more likely to become damaged and begin to degrade in the concentrate before addition to the seawater sample. It is possible that native bacteria are adapted or primed to quickly digest local viruses and lysis products compared to 'exotic' lab cultured viruses. Our results show distinct variability in degadation rates between different marine environments. The rate of breakdown of radiolabeled virus material was significantly faster in richer waters (Paradise Cove, Two Harbors) than in less active waters (offshore California, Villefranche Bay, $t$-test, $p<0.05$ ). We speculate that trophic status has some relation to the rates of degradation of virus particles. Biologically active and heat-labile dissolved organic molecules, such as enzymes, are important contributors to breakdown (Suttle \& Chen 1992, Suttle et al. 1992, Noble \& Fuhrman 1997), and in more active waters, increased levels of microbial and protist growth will tend to increase the production of free- and membrane-bound nucleases and proteases. Where rates of degradation are very slow, as in the offshore California waters $\left(1.0 \% \mathrm{~h}^{-1}\right.$, turnover time of $\left.>3 \mathrm{~d}\right)$, it is possible that reduced biochemical and enzymatic degradation of viruses occurred due to low bacterial activity (Noble \& Fuhrman 1997). Results from experiments using fluorescently labeled viruses (FLV) as tracers of virus removal, performed at the same time at the Two Harbors and offshore California locations, indicated similar turnover times for the virus populations (Noble \& Fuhrman 1998a).

Our results indicate rapid turnover of viruses and viral lysis products. Therefore, a prolonged incubation with ${ }^{3} \mathrm{H}$-labeled substrates and ${ }^{33} \mathrm{PO}_{4}$ for labeling of the virus population may result in a concentrate that includes labile HMW and LMW viral lysis products that are being degraded even during the concentration steps (Amon \& Benner 1996, Benner et al. 1997). This confounds our ability to interpret rates of degradation seen in the natural environment, especially because the most labile materials will be degraded and used for growth within hours. This is likely to have occurred in the experiments with both Villefranche Bay and offshore California waters, where less than $50 \%$ of the material at the beginning of the experiment was characterized as HMW virus material. Also, tritiated substrates may end up respired as water and diluted away or degraded, while ${ }^{33} \mathrm{P}$ products, inorganic or organic $\mathrm{P}$ can be continually recycled. Even in waters that are not extremely oligotrophic, we have experienced difficulty in successful labeling of viral lysis products with ${ }^{33} \mathrm{PO}_{4}$. During the incubation period, this substrate may be rapidly recycled as cellular components, especially phospholipids, of microorganisms and removed by prefiltration before the concentration steps. In general, rates of degradation of HMW material are likely to be underestimates as during the concentration steps the most reactive products will be degraded and taken up while the least reactive products will accumulate.

In all of the experiments, rates of degradation indicate relatively rapid turnover of viruses and viral lysis products. The shift of radiolabeled HMW material into LMW material in these experiments illustrates the breakdown of virus particles and viral lysis products, probably by enzymes. This LMW material can contain bioavailable small organic or inorganic molecules (Hollibaugh \& Azam 1983, Simon \& Azam 1989, Jørgensen \& Jacobsen 1996, Middelboe et al. 1996). In the most active waters studied, the HMW material exhibited a turnover time of ca $1 \mathrm{~d}$, indicating rapid cycling.

Microbial uptake was difficult to measure, however, possibly for a few reasons. First, during the virus labeling process the most rapidly degraded and usable components probably are taken up by the bacterial 
cells (which are removed by the prefiltration), leaving behind relatively refractory material that later lends to an underestimation in the rates of microbial uptake and degradation. Second, inefficient use or multi-step transfer of ${ }^{3} \mathrm{H}$-labeled organics would result in ${ }^{3} \mathrm{H}_{2} \mathrm{O}$ appearing in the LMW fraction (Jørgensen 1992). Measurements of microbial respiration, by looking at ${ }^{3} \mathrm{H}_{2} \mathrm{O}$, were attempted in 2 of the 4 experiments, but were unsuccessful. Third, at time zero there was already a measurable background amount of radiolabel found on the $0.2 \mu \mathrm{m}$ filters. We suspect that when HMW concentrate is added to the incubation containers, a certain amount of HMW material sticks immediately to the first particle (probably a bacterioplankton or phytoplankton cell) that it encounters or to the filter during filtration. In only 1 experiment (Villefranche Bay) was the amount of radiolabeled material found in the $>0.2 \mu \mathrm{m}$ size fraction at $0 \mathrm{~h}$ undetectable, probably because the densities of particles onto which the virus particles could adsorb were very low.

The microbial uptake of degraded radiolabeled virus components was readily measurable in the oligotrophic waters of Villefranche Bay. Microbial uptake of both ${ }^{3} \mathrm{H}$ and ${ }^{33} \mathrm{P}$ radiolabels was detectable, although the uptake of the ${ }^{33} \mathrm{p}$ radiolabel was more dramatic. It seemed that the majority of the ${ }^{33} \mathrm{P}$ taken up by microbes may have come from the LMW pool, although it is difficult to verify the loss of one pool as the direct gain in another. Villefranche Bay is thought to be phosphate limited (Dolan et al. 1995, Thingstad et al. 1996), and it has been suggested recently that viral infection of bacterioplankton may be an important route for phosphate recycling (Blackburn et al. 1996, Middelboe et al. 1996, Zweifel et al. 1996). The results of our experiments in Villefranche Bay may be an example of this recycling, as the microbial uptake of the ${ }^{33}$ P-labeled virus material was rapid. Other experiments also performed in Villefranche Bay demonstrated the uptake of phosphate by bacteria, and subsequent release into dissolved forms, possibly explained in part by viral lysis (Thingstad et al. 1996). Our results demonstrate that there may be an important link between phosphate-rich cell lysis products and uptake of phosphate by microorganisms, at least in these waters.

Our experiments demonstrate degradation of viruses and viral lysis products at rates of a few percent per hour, indicating turnover times of the material on the order of hours to a few days. With viral infection of bacterial cells and subsequent lysis accounting for the release of a significant percentage of the total bacterial biomass, viral lysis products are likely to be important sources of organic $N$ and $P$, especially in nutrient-limited systems. In Amon \& Benner (1996), and Benner et al. (1997), a model was presented stating that 'new'
HMW DOM is more bioreactive and less diagenetically altered than the bulk of LMW DOM. In their study, the 'younger', 'fresher', larger-sized molecules were found to be the most bioreactive, and during decomposition, organic matter becomes more diagenetically altered, less bioreactive, and smaller (Amon \& Benner 1996). In our experiments, where the radiolabeled virus material was used to trace the fates of virus material produced by fresh cell lysis, all of the virus material is 'new', and to varying extents available for biological processes. Our results support other recent findings that heightened viral infection of bacterial populations may boost bacterial productivity (Noble et al. 1999). If the work of Benner et al. (1997) and Amon \& Benner (1996) is applicable, bioreactive molecules between the size of the LMW material and HMW material that are the result of bacterial infection should be good candidates for rapid recycling. We demonstrated that microbial uptake of ${ }^{33} \mathrm{P}$-iabeled virus material was rapid in nutrient-limited waters, where the regeneration of phosphorus is vital to microbial growth. This research is a first step towards understanding the fate of products of cell lysis. Future work which defines the biochemical characteristics of components of bacterial cell lysis and mechanisms of viral degradation will further our understanding of the importance of virus-mediated processes to biogeochemical cycling in the marine microbial food web.

Acknowledgements. Partly financed by EU-MAST3 project 'MEDEA' contract MAS3-CT95-0016. Research by R.T.N. supported by NSF Grant OCE No. 9634028, USC Sea Grant, and a scholarship from the ARCS Foundation. We thank the crew of the RV 'Point Sur' during the cruises in both 1995 and in 1997, and A. A. Davis, X. Hernandez, C. C. Ouverney, J. F. Griffith, and J. Herndon for assistance in sampling.

\section{LITERATURE CITED}

Amon RMW, Benner R (1996) Bacterial utilization of different size classes of dissolved organic matter. Limnol Oceanogr 41(1):41-51

Benner R, Biddanda B, Black B, McCarthy M (1997) Abundance, size distribution, and stable carbon and nitrogen isotopic compositions of marine organic matter isolated by tangential flow ultrafiltration. Mar Chem 57(3-4):243-263

Bergh $\varnothing$, Børsheim KY, Bratbak G, Heldal M (1989) High abundance of viruses found in aquatic environments. Nature 340:467-468

Blackburn N, Zweifel UL, Hagström $\AA$ (1996) Cycling of dissolved organic matter. II. A model analysis. Aquat Microb Ecol 11:79-90

Børsheim KY (1993) Native marine bacteriophages. FEMS Microbiol Ecol 102:141-159

Børsheim KY, Bratbak G, Heldal M (1990) Enumeration and biomass estimation of planktonic bacteria and viruses by transmission electron microscopy. Appl Environ Microbiol $56: 352-356$

Bratbak G, Heldal M, Norland S, Thingstad TF (1990) Viruses 
as partners in spring bloom microbial trophodynamics. Appl Environ Microbiol 56:1400-1405

Cochlan WP, Wikner J, Steward GF, Smith DC, Azam F (1993) Spatial distribution of viruses, bacteria and chlorophyll a in neritic, oceanic and estuarine environments. Mar Ecol Prog Ser 92:77-87

Dolan JR, Thingstad TF, Rassoulzadegan F (1995) Phosphate transfer between microbial size-fractions in Villefranche Bay (N.W. Mediterranean Sea), France, in autumn 1992. Ophelia 41:71-85

Ferguson RL, Buckley EN, Palumbo AV (1984) Response of marine bacterioplankton to differential filtration and confinement. Appl Environ Microbiol 47:49-55

Fuhrman JA (1992) Bacterioplankton roles in cycling of organic matter: the microbial food web. In: Falkowski PG, Woodhead AD (eds) Primary productivity and biogeochemical cycles in the sea. Plenum Press, New York, p 361-383

Fuhrman JA, Azam F (1982) Thymidine incorporation as a measure of heterotrophic bacterioplankton production in marine surface waters: evaluation and field results. Mar Biol 66:109-120

Fuhrman JA, Noble RT (1995) Viruses and protists cause similar bacterial mortality in coastal seawater. Limnol Oceanogr 40(7):1236-1242

Fuhrman JA, Suttle CA (1993) Viruses in marine planktonic systems. Oceanography 6:51-63

Heldal M, Bratbak G (1991) Production and decay of viruses in aquatic environments. Mar Ecol Prog Ser 72:205-212

Hennes KP, Suttle CA (1995) Direct counts of viruses in natural waters and laboratory cultures by epifluorescence microscopy. Limnol Oceanogr 40(6):1050-1055

Hollibaugh JT, Azam F (1983) Microbial degradation of dissolved proteins in seawater. Limnol Oceanogr 28(6): 1104-1116

Jiang SC, Paul JH (1994) Seasonal and diel abundance of viruses and occurrence of lysogeny/bacteriocinogeny in the marine environment. Mar Ecol Prog Ser 104(1-2): $163-172$

Jørgensen NOG (1992) Incorporation of [3H] leucine and $[3 \mathrm{H}]$ valine into protein of freshwater bacteria: uptake kinetics and intracellular isotope dilution. Appl Environ Microbiol 58(11):3638-3646

Jørgensen NOG, Jacobsen CS (1996) Bacterial uptake and utilization of dissolved DNA. Aquat Microb Ecol 11: 263-270

Kapuscinski RB, Mitchell R (1980) Processes controlling virus inactivation in coastal waters. Water Res 14:363-371

Lee S, Fuhrman JA (1991) Spatial and temporal variation of natural bacterioplankton assemblages studied by total genomic DNA cross-hybridization. Limnol Oceanogr 36: $1277-1287$

Middelboe M, Jørgensen NOG, Kroer N (1996) Effects of viruses on nutrient turnover and growth efficiency of noninfected marine bacterioplankton. Appl Environ Microbiol 62:1991-1997

Mitchell R, Jannasch HW (1969) Processes controlling virus inactivation in seawater. Environ Sci Technol 3:941-945

Moebus K (1980) A method for the detection of bacteriophages from ocean water. Helgol Meeresunters 34:1-14

Moebus K, Nattkemper H (1983) Taxonomic investigations of bacteriophage sensitive bacteria isolated from marine waters. Helgol Meeresunters 36:357-373

Murray AG, Jackson GA (1992) Viral dynamics: a model of the effects of size, shape, motion and abundance of singlecelled planktonic organisms and other particles. Mar Ecol Prog Ser 89:103-116

Noble RT, Fuhrman JA (1997) Virus decay and its causes in coastal waters. Appl Environ Microbiol 63(1):77-83

Noble RT, Fuhrman JA (1998a) Estimates of virus production and removal rates: implications to bacterial mortality in the marine environment. Proceedings of the 8th International Symposium on Microbial Ecology, Halifax, NS. Atlantic Canada Society for Microbial Ecology, Halifax

Noble RT, Fuhrman JA (1998b) Use of SYBR Green I for rapid epifluorescence counts of marine viruses and bacteria. Aquat Microb Ecol 14(2):113-118

Noble RT, Middelboe M, Fuhrman JA (1999) Effects of viral enrichment on the mortality and growth of heterotrophic bacterioplankton. Aquat Microb Ecol 18:1-13

Parsons TR, Maita Y, Lalli CM (1984) A manual of chemical and biological methods for seawater analysis. Pergamon Press, New York

Paul JH, Rose JB, Jiang SC, Kellogg CA, Dickson L (1993) Distribution of viral abundance in the reef environment of Key Largo, Florida. Appl Environ Microbiol 59(3):718-724

Proctor LM, Fuhrman JA, Ledbetter MC (1988) Marine bacteriophages and bacterial mortality. EOS Trans Am Geophys Union 69:1111-1112

Simon M, Azam F (1989) Protein content and protein synthesis rates of planktonic marine bacteria. Mar Ecol Prog Ser 51:201-213

Spencer R (1955) A marine bacteriophage. Nature 175:690

Staley JT, Konopka A (1985) Measurement of in situ activities of nonphotosynthetic microorganisms in aquatic and terrestrial habitats. Annu Rev Microbiol 39:321-346

Steward GF, Wikner J, Smith DC, Cochlan WP, Azam F (1992) Estimation of virus production in the sea: I. Method development. Mar Microb Food Webs 6(2):57-78

Steward GF, Smith DC, Azam F (1996) Abundance and production of bacteria and viruses in the Bering and Chukchi Seas. Mar Ecol Prog Ser 131:287-300

Suttle CA, Chen F (1992) Mechanisms and rates of decay of marine viruses in seawater. Appl Environ Microbiol 58: $3721-3729$

Suttle CA, Chen F, Chan AM (1992) Marine viruses: decay rates, diversity and ecological implications. In: Nash CC II (ed) International marine biotechnology conference 'IMBC91': short communications of the invited lectures ecology. W Brown Co, Dubuque, IA, p 153-163

Thingstad TF, Dolan JR, Fuhrman JA (1996) Loss rate of an oligotrophic bacterial assemblage as measured by ${ }^{3} \mathrm{H}$-thymidine and ${ }^{32} \mathrm{PO}_{4}$ : good agreement and near-balance with production. Aquat Microb Ecol 10:29-36

Weinbauer MG, Fuks D, Peduzzi P (1993) Distribution of viruses and dissolved DNA along a coastal trophic gradient in the Northern Adriatic Sea. Appl Environ Microbiol 59(12):4074-4082

Weinbauer MG, Fuks D. Puskaric S, Peduzzi P (1995) Diel, seasonal, and depth-related variability of viruses and dissolved DNA in the Northern Adriatic Sea. Microb Ecol 30: $25-41$

Wilcox RM, Fuhrman JA (1994) Bacterial viruses in coastal seawater: lytic rather than lysogenic production. Mar Ecol Prog Ser 114:35-45

Wommack KE, Hill RT, Muller TA, Colwell RR (1996) Effects of sunlight on bacteriophage viability and structure. Appl Environ Microbiol 62(4):1336-1341

Zachary A (1976) Physiology and ecology of bacteriophages of the marine bacterium Beneckea natriegens: salinity. Appl Environ Microbiol 31(3):415-422

ZoBell CE (1946) Marine microbiology. Waltham, MA

Zweifel UL, Blackburn N, Hagström $\AA$ (1996) Cycling of marine dissolved organic matter. I. An experimental system. Aquat Microb Ecol 11:65-77 